
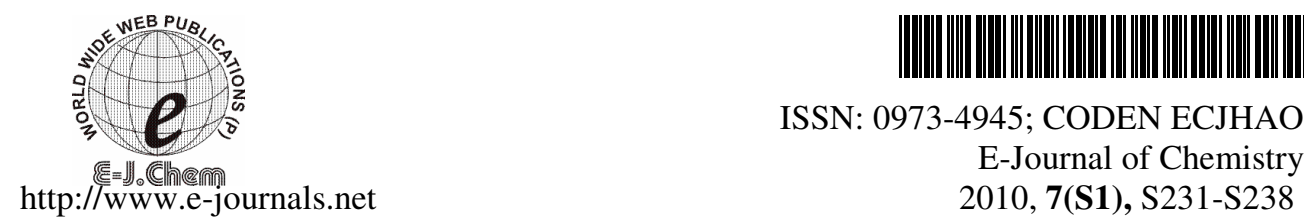

ISSN: 0973-4945; CODEN ECJHAO

E-Journal of Chemistry 2010, 7(S1), S231-S238

\title{
Preparation and Characterization of Cyano Complexes of Oxotungsten(IV) with Mannich Base Ligands
}

\author{
MOHITA SHARMA, MOHD SALEEM, \\ BALGAR SINGH, H. N. SHEIKH* ${ }^{*}$ and B. L. KALSOTRA \\ Department of Chemistry \\ University of Jammu, Jammu-180006, India \\ hnsheikh@ rediffmail.com
}

Received 10 April 2010; Accepted 22 May 2010

\begin{abstract}
Oxocyanotungsten(IV) complexes, $\left(\mathrm{Ph}_{3} \mathrm{P}\right)_{2} \mathrm{NH}_{2}\left[\mathrm{WO}(\mathrm{CN})_{3} \mathrm{~L}-\mathrm{L}\right]$. $3 \mathrm{H}_{2} \mathrm{O}$ and $\mathrm{Cs}\left[\mathrm{WO}(\mathrm{CN})_{3} \mathrm{~L}-\mathrm{L}\right] \cdot \mathrm{H}_{2} \mathrm{O}$ (where $\mathrm{L}-\mathrm{L}=$ morpholinobenzyl benzamide (MBB), piperidinobenzyl benzamide (PBB), piperidinobenzyl urea (PBU), piperidinobenzyl thiourea (PBTU), morpholinobenzyl urea (MBU) and morpholinobenzyl thiourea (MBTU)) were synthesized. The complexes have been prepared by the reaction of $\mathrm{K}_{3} \mathrm{Na} \quad\left[\mathrm{WO}_{2}(\mathrm{CN})_{4}\right] \cdot 6 \mathrm{H}_{2} \mathrm{O}$ with morpholinobenzyl urea and related ligands in aqueous solution around $\mathrm{pH}$ of 78. These have been isolated as bis(triphenylphosphine)iminium or cesium salts. The complexes have been characterized by elemental analysis, IR, ${ }^{1} \mathrm{H}$ NMR, UV-Vis spectra, magnetic susceptibility, conductivity measurements and TGA/DTA studies.
\end{abstract}

Keywords: Bis(triphenylphosphine)iminium salts, Mannich base, Synthesis, Cyano complex.

\section{Introduction}

A series of oxocyano complexes of molybdenum(IV) and tungsten(IV) with various monodentate ligands of formula $\left[\mathrm{M}(\mathrm{CN})_{4} \mathrm{OL}\right]^{\mathrm{n}-}$, where $\mathrm{L}=\mathrm{NCS}^{-}, \mathrm{N}_{3}^{-}, \mathrm{F}^{-}, \mathrm{HCN}$ and py, $\mathrm{M}=\mathrm{Mo}$ or $\mathrm{W}$ have been synthesized and characterized ${ }^{1-3}$. The complexes of the type $\left(\mathrm{PPh}_{4}\right)_{3}\left[\mathrm{~W}(\mathrm{CN})_{5} \mathrm{O}\right] .7 \mathrm{H}_{2} \mathrm{O}$ have been found to react with molecular oxygen and their kinetics and mechanism have been studied ${ }^{4}$. The protonation of the dioxotetracyano complexes of rhenium $(\mathrm{V})$ and technetium $(\mathrm{V})$ result in the formation of the $\left[\mathrm{MO}(\mathrm{OH})(\mathrm{CN})_{4}\right]^{(\mathrm{n}+1)-}$ and $\left[\mathrm{MO}\left(\mathrm{H}_{2} \mathrm{O}\right)(\mathrm{CN})_{4}\right]^{\mathrm{n}-}$ complexes and have been studied in detail over the past few years ${ }^{5,6}$. Dioxotetracyanotungstate(IV) and dioxotetracyanomolybdate(IV) ions may be protonated to form the oxo-hydroxo and oxo-aqua complexes, 


$$
\begin{aligned}
& {\left[\mathrm{MO}_{2}(\mathrm{CN})_{4}\right]^{4-}+\mathrm{H}^{+}=\left[\mathrm{MO}(\mathrm{OH})(\mathrm{CN})_{4}\right]^{3-}} \\
& {\left[\mathrm{MO}(\mathrm{OH})(\mathrm{CN})_{4}\right]^{3-}+\mathrm{H}^{+}=\left[\mathrm{MO}\left(\mathrm{H}_{2} \mathrm{O}\right)(\mathrm{CN})_{4}\right]^{2-}}
\end{aligned}
$$

The existence of the protonated forms was duly established by means of the structure ${ }^{7,8}$ determination of $\left\{\mathrm{Cr}(\mathrm{en})_{3}\right\}\left[\mathrm{MoO}(\mathrm{OH})(\mathrm{CN})_{4}\right] \cdot \mathrm{H}_{2} \mathrm{O},\left\{\mathrm{Pt}(\mathrm{en})_{2}\right\}\left[\mathrm{MoO}\left(\mathrm{H}_{2} \mathrm{O}\right)(\mathrm{CN})_{4}\right] \cdot 2 \mathrm{H}_{2} \mathrm{O}$ and $\left(\mathrm{PPh}_{4}\right)_{2}\left[\mathrm{MoO}\left(\mathrm{H}_{2} \mathrm{O}\right)(\mathrm{CN})_{4}\right] \cdot 4 \mathrm{H}_{2} \mathrm{O}$. These protonated species can undergo substitution reactions with mono-(aqua ligand substitution) and bidentate (aqua and cyano ligand substitution) nucleophiles ${ }^{9-16}$. The protonation behaviour as well as the cyanide exchange of these systems has recently been the subject of carbon-13 and oxygen-17 NMR studies in order to investigate the water and cyanide exchange of these complexes.

Previous studies of the substitution reactions of these oxoaqua complexes included different monodentate nucleophiles such as $\mathrm{F}^{-}, \mathrm{N}_{3}^{-}, \mathrm{NCS}^{-}$, py and substituted thioureas for the tungsten(IV) and rhenium(V) complexes ${ }^{11-14}$. Only reactions of the $\mathrm{F}^{-}$and $\mathrm{CN}^{-} / \mathrm{HCN}$ ions with the molybdenum(IV) complex could be studied due to the high lability of the coordinated aqua ligand in the $\left[\mathrm{MoO}\left(\mathrm{H}_{2} \mathrm{O}\right)(\mathrm{CN})_{4}\right]^{2-}$ complex ${ }^{9}$. Thus, it was impossible to do extensive kinetic studies, specifically high pressure studies, on the substitution reactions of the $\left[\mathrm{MoO}\left(\mathrm{H}_{2} \mathrm{O}\right)(\mathrm{CN})_{4}\right]^{2-}$ complex. The kinetic study of the monodentate substitution $\left(\mathrm{N}_{3}^{-}, \mathrm{NCS}^{-}\right.$, py) of the aqua ligand of the $\left[\mathrm{WO}\left(\mathrm{H}_{2} \mathrm{O}\right)(\mathrm{CN})_{4}\right]^{2-}$ complex showed that a linear free energy relationship between $\ln k_{L}$ and $\ln K_{L}\left(k_{L}\right.$ is the hydrolysis rate constant and $K_{L}$ is the stability constant for the $\left[\mathrm{WO}(\mathrm{L})(\mathrm{CN})_{4}\right]^{\mathrm{n}-}$ ) exists and the existence of this relationship points towards a dissociative mechanism for these substitution reactions.

The $\left[\mathrm{WO}\left(\mathrm{H}_{2} \mathrm{O}\right)(\mathrm{CN})_{4}\right]^{2-}$ complexes can also undergo substitution by bidentate ligands. The crystal structure determinations of the products ${ }^{17-19}$ of the reactions between the oxoaqua complexes and bidentate ligands showed that the aqua ligand and one of the cyano ligands in the equitorial plane are substituted by the entering bidentate nucleophiles. It is expected that the aqua ligand will be substituted first during the two step process, since the metal-aqua bond is usually much weaker than a metal-cyano bond in this type of complexes, especially as a result of the large trans influence of the oxo ligand. The crystal structure determination of the $\left[\mathrm{WO}(\mathrm{pic})(\mathrm{CN})_{4}\right]^{2-}($ pic $=$ pyridine2-carboxylate) showed that an oxygen atom of the carboxylic group is bonded trans to the nitrido ligand and that the nitrogen atom is bonded trans to a cyano ligand in the equitorial plane of the octahedral complex. This is interpreted to mean that the aqua ligand is indeed substituted first, since it is known that the oxygen atom of the carboxylic ligand will bend before the nitrogen atom in this type of bidentate ligand. The substitution reactions of the $\left[\mathrm{WO}\left(\mathrm{H}_{2} \mathrm{O}\right)(\mathrm{CN})_{4}\right]^{2-}$ complex with monodentate ligands are about a 1000 times faster compared to the bidentate substitution reactions indicating that a dissociative mechanism is operative. This gives a strong indication that the substitution of the aqua ligand is the fast first reaction. The substitution of the cyano ligand and the simultaneous ring closure of the chelate ring is a relatively slow reaction and this reaction is the rate determining step in the overall process ${ }^{20}$. In the present chapter, we have prepared oxotungsten(IV) complexes by reacting $\left[\mathrm{WO}\left(\mathrm{H}_{2} \mathrm{O}\right)(\mathrm{CN})_{4}\right]^{2-}$ with the bidentate ligand, viz; morpholinobenzyl benzamide (MBB), piperidinobenzyl benzamide (PBB), piperidinobenzyl urea (PBU), piperidinobenzyl thiourea (PBTU), morpholinobenzyl urea (MBU) and morpholinobenzyl thiourea (MBTU) when the aqua and one cyano ligands are replaced by the ligand and complexes having composition $\left[\mathrm{WO}(\mathrm{CN})_{3} \mathrm{~L}-\mathrm{L}\right]^{-}$were obtained. The structures of ligands are given in Scheme 1. 


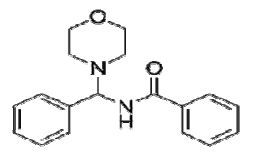

MBB (a)
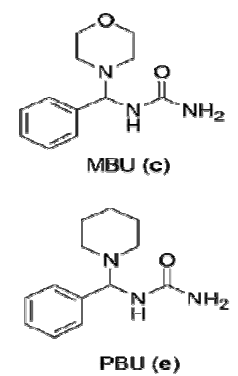

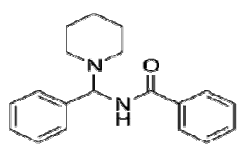

PBB (b)
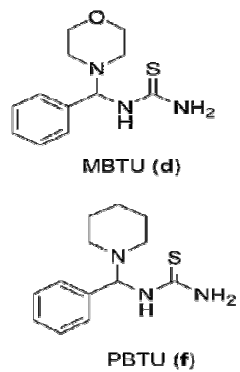

\section{Experimental}

\section{Scheme 1}

Morpholine (Fluka), piperidine (SDS) and pyrrolidine (Fluka) were purified by distillation after keeping these bases over potassium hydroxide overnight. Urea (Merck), thiourea (Ranbaxy), benzaldehyde (Qualigens) and sodium tungstate dihydrate (Sisco-Chem-Industries, Bombay) were used as supplied. Bis(triphenylphosphine)iminium chloride $\left[\left(\mathrm{Ph}_{3} \mathrm{P}\right)_{2} \mathrm{~N}\right] \mathrm{Cl}$, cesium chloride and other laboratory reagents were of analytical grade (Sigma, Aldrich) and used as supplied. The ligands were prepared by the reported method ${ }^{21,22}$.

\section{Methods and instruments}

The analysis of tungsten was carried out gravimetrically by the reported method ${ }^{23}$. Carbon, hydrogen, nitrogen and sulfur analyses were performed by microanalytical methods. IR spectra of the complexes over the region $400-4000 \mathrm{~cm}^{-1}$ were recorded on a FT-IR spectrophotometer- vector-22 using a $\mathrm{KBr}$ disc. Molar conductivity in DMSO $\left(10^{-3} \mathrm{M}\right)$ at room temperature was measured by an Elico conductivity bridge type CM82T having a conductivity cell with cell constant of 0.90 . TGA/DTA studies have been performed in the temperature range of $25-800{ }^{\circ} \mathrm{C}$ on a DTG 60 Thermoanalyser under nitrogen atmosphere at a heating rate of $10^{\circ} \mathrm{C}$ per minute.

\section{Preparation of $\mathrm{K}_{3} \mathrm{Na}\left[\mathrm{WO}_{2}(\mathrm{CN})_{4}\right] .6 \mathrm{H}_{2} \mathrm{O}$}

$10.0 \mathrm{~g}(0.03 \mathrm{~mol})$ of sodium tungstate dihydrate $\left(\mathrm{Na}_{2} \mathrm{WO}_{4} .2 \mathrm{H}_{2} \mathrm{O}\right), 3.0 \mathrm{~g}(0.063 \mathrm{~mol})$ of sodium borohydride $\left(\mathrm{NaBH}_{4}\right)$ and $5.0 \mathrm{~g}(0.077 \mathrm{~mol})$ of potassium cyanide $(\mathrm{KCN})$ were dissolved in $100 \mathrm{~cm}^{3}$ water followed by drop wise addition of $5 \mathrm{~cm}^{3}(0.08 \mathrm{~mol})$ acetic acid over $10 \mathrm{~min}$. An additional $5.0 \mathrm{~g}(0.077 \mathrm{~mol})$ of potassium cyanide $(\mathrm{KCN})$ was added, followed by drop wise addition of another $5 \mathrm{~cm}^{3}(0.08 \mathrm{~mol})$ acetic acid $\left(\mathrm{CH}_{3} \mathrm{COOH}\right)$ over $10 \mathrm{~min}$. $20 \mathrm{~g}(0.05 \mathrm{~mol})$ of solid sodium hydroxide $(\mathrm{NaOH})$ was added slowly to the solution followed by the slow addition of $30 \mathrm{~cm}^{3}$ ethanol. The brown colored shiny crystals were decanted and washed with $100 \mathrm{~cm}^{3}$ portions of ethanol: water (9:1) mixture (Yield $\sim 70 \%$ ).

\section{Preparation of $\left(\mathrm{Ph}_{3} \mathrm{P}\right)_{2} \mathrm{NH}_{2}\left[\mathrm{WO}(\mathrm{CN})_{3} \mathrm{~L}-\mathrm{L}\right] .3 \mathrm{H}_{2} \mathrm{O}$}

$\left(\mathrm{Ph}_{3} \mathrm{P}\right)_{2} \mathrm{NH}_{2}\left[\mathrm{WO}(\mathrm{CN})_{3} \mathrm{~L}-\mathrm{L}\right] .3 \mathrm{H}_{2} \mathrm{O}$ (1-6), shown in Table 1 (where $\mathrm{L}-\mathrm{L}=$ morpholinobenzyl benzamide (MBB), piperidinobenzyl benzamide (PBB), piperidinobenzyl urea 
(PBU), piperidinobenzyl thiourea (PBTU), morpholinobenzyl urea (MBU) and morpholinobenzyl thiourea (MBTU)) was prepared by dissolving $3.31 \mathrm{~g}(5.8 \mathrm{mmol})$ of $\mathrm{K}_{3} \mathrm{Na}$ [ $\left.\mathrm{WO}_{2}(\mathrm{CN})_{4}\right] \cdot 6 \mathrm{H}_{2} \mathrm{O}$ in $15 \mathrm{~mL}$ of water and to this was added $24 \mathrm{mmol}$ of ligand; MBB (7.01 g), PBB (7.06 g), PBU (5.59 g), PBTU (5.98 g), MBU (5.64 g) and MBTU (6.03 g) in $20 \mathrm{~mL}$ of ethanol. The $\mathrm{pH}$ of the solution was adjusted to 8 with $0.5 \mathrm{M}$ acetic acid. It was heated to about $50{ }^{\circ} \mathrm{C}$ for 20 minutes followed by addition of $3.44 \mathrm{~g}(6 \mathrm{mmol})$ of $\left(\mathrm{Ph}_{3} \mathrm{P}\right)_{2} \mathrm{NCl}$ in $15 \mathrm{~mL}$ of water. An oily product which sticks to the beaker and the glass rod was obtained on stirring. The solution was decanted and the oily product was extracted with ethanol when complexes precipitated. The precipitate was filtered off, washed several times with water and dried in vacuum (yield 40-48\%).

\section{Preparation of $\mathrm{Cs}\left[\mathrm{WO}(\mathrm{CN})_{3} \mathrm{~L}-\mathrm{L}\right] \cdot \mathrm{H}_{2} \mathrm{O}$}

$\mathrm{Cs}\left[\mathrm{WO}(\mathrm{CN})_{3} \mathrm{~L}-\mathrm{L}\right] \cdot \mathrm{H}_{2} \mathrm{O}$ (7-12), shown in Table 1 (where $\mathrm{L}-\mathrm{L}=$ morpholinobenzyl benzamide(MBB), piperidinobenzyl benzamide (PBB), piperidinobenzyl urea (PBU), piperidinobenzyl thiourea (PBTU), morpholinobenzyl urea (MBU) and morpholinobenzyl thiourea (MBTU)) was prepared by dissolving $3.31 \mathrm{~g}(5.8 \mathrm{mmol})$ of $\mathrm{K}_{3} \mathrm{Na}\left[\mathrm{WO}_{2}(\mathrm{CN})_{4}\right] \cdot 6 \mathrm{H}_{2} \mathrm{O}$ in $15 \mathrm{~mL}$ of water and to this was added $24 \mathrm{mmol}$ of ligands; MBB (7.01 g), PBB (7.06 g), PBU (5.59 g), PBTU (5.98 g), MBU (5.64 g) and MBTU (6.03 g), in $20 \mathrm{~mL}$ of ethanol. The pH of the solution was adjusted to 7.0 with $0.5 \mathrm{M}$ acetic acid. A $1.0 \mathrm{~g}$ sample of cesium chloride $(6 \mathrm{mmol})$ was dissolved in $10 \mathrm{~mL}$ of water. Both the solutions were heated to about $35{ }^{\circ} \mathrm{C}$ and mixed. The orange-red solution initially obtained on standing for about $24 \mathrm{~h}$ at room temperature leads to the formation of complexes. These were filtered off and washed by ethanol (yield 32-40\%).

\section{Results and Discussion}

The reaction of $\left[\mathrm{WO}\left(\mathrm{H}_{2} \mathrm{O}\right)(\mathrm{CN})_{4}\right]^{2-}$ with morpholinobenzyl benzamide (MBB), piperidinobenzyl benzamide (PBB), piperidinobenzyl urea (PBU), piperidinobenzyl thiourea (PBTU), morpholinobenzyl urea (MBU) and morpholinobenzyl thiourea (MBTU) takes place according to the equation

$$
\left[\mathrm{WO}\left(\mathrm{H}_{2} \mathrm{O}\right)(\mathrm{CN})_{4}\right]^{2-}+\mathrm{L}-\mathrm{L} \rightleftharpoons\left[\mathrm{WO}(\mathrm{CN})_{3} \mathrm{~L}-\mathrm{L}\right]^{-}+\mathrm{H}_{2} \mathrm{O}+\mathrm{CN}^{-}
$$

Leading to the formation of complex $\left[\mathrm{WO}(\mathrm{CN})_{3} \mathrm{~L}-\mathrm{L}\right]^{-}$where $\mathrm{L}-\mathrm{L}=\mathrm{MBB}, \mathrm{PBB}, \mathrm{PBU}$, PBTU, MBU and MBTU. The equilibrium lies strongly towards the reactants, formation of product complex can be observed only in concentrated solutions in the presence of large excess of ligand.

The complexes 1-6 (Table 1) were isolated as bis(triphenylphosphine)iminium salts and 7-12 (Table 1) were isolated as cesium salts. The $\left(\mathrm{Ph}_{3} \mathrm{P}\right)_{2} \mathrm{NH}_{2}^{+}$cation or $\mathrm{Cs}^{+}$cation form insoluble salts with the product complex, thus shifting the equilibrium to the right.

The analytical and spectroscopic results (Tables 1-3) showed that all the complexes are mononuclear with general formula, $\left(\mathrm{Ph}_{3} \mathrm{P}\right)_{2} \mathrm{NH}_{2}\left[\mathrm{WO}(\mathrm{CN})_{3} \mathrm{~L}-\mathrm{L}\right] \cdot 3 \mathrm{H}_{2} \mathrm{O}$ (1-6) and $\mathrm{Cs}$ [WO $\left.(\mathrm{CN})_{3} \mathrm{~L}-\mathrm{L}\right] \cdot \mathrm{H}_{2} \mathrm{O}$ (7-12) where $\mathrm{L}-\mathrm{L}=\mathrm{MBB}, \mathrm{PBB}, \mathrm{PBU}, \mathrm{PBTU}, \mathrm{MBU}$ and MBTU.

All the complexes are colored, stable, insoluble in water but soluble in organic solvents like dichloromethane, $N, N$ 'dimethylformamide and dimethylsulphoxide.

\section{Conductance and magnetic measurements}

The molar conductance of these complexes in $N, N$ 'dimethylformamide are in the range of $79-98 \mathrm{ohm}^{-1} \mathrm{~cm}^{2} \mathrm{~mol}^{-1}$ (Table 1) which indicates the uni-univalent electrolytic nature of the complexes. All the complexes are diamagnetic in nature consistent with a spin paired $\mathrm{d}^{2}$ configuration $^{24}$. 
Table 1. Analytical data and some physical properties of oxotungsten(IV) complexes

\begin{tabular}{|c|c|c|c|c|c|c|c|c|c|}
\hline \multirow[b]{2}{*}{$\overbrace{\dot{L}}^{\circ}$} & \multirow[b]{2}{*}{$\begin{array}{l}\text { Complex } \\
\text { (Mol. Wt.) }\end{array}$} & \multirow[b]{2}{*}{ Colour } & \multirow{2}{*}{ 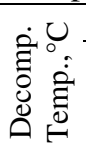 } & \multicolumn{5}{|c|}{ Found (Calcd.) \% } & \multirow{2}{*}{ 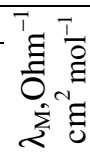 } \\
\hline & & & & $\mathrm{C}$ & $\mathrm{H}$ & $\mathrm{N}$ & $S$ & W & \\
\hline 1. & $\begin{array}{l}\left(\mathrm{Ph}_{3} \mathrm{P}\right)_{2} \mathrm{NH}_{2}\left[\mathrm{WO}(\mathrm{CN})_{3} \mathrm{MBB}\right] .3 \mathrm{H}_{2} \mathrm{O} \\
\mathrm{C}_{57} \mathrm{H}_{60} \mathrm{P}_{2} \mathrm{~N}_{6} \mathrm{O}_{6} \mathrm{~W}(1170.68)\end{array}$ & $\begin{array}{l}\text { Light } \\
\text { Brown }\end{array}$ & 201 & $\begin{array}{c}58.43 \\
(58.48)\end{array}$ & $\begin{array}{c}5.10 \\
(5.16)\end{array}$ & $\begin{array}{c}7.12 \\
(7.17)\end{array}$ & $\begin{array}{ll}\ldots . . & \\
\ldots . .\end{array}$ & $\begin{array}{c}15.68 \\
(15.71)\end{array}$ & 89.4 \\
\hline 2. & $\begin{array}{l}\left(\mathrm{Ph}_{3} \mathrm{P}\right)_{2} \mathrm{NH}_{2}\left[\mathrm{WO}(\mathrm{CN})_{3} \mathrm{PBB}\right] .3 \mathrm{H}_{2} \mathrm{O} \\
\mathrm{C}_{58} \mathrm{H}_{62} \mathrm{P}_{2} \mathrm{~N}_{6} \mathrm{O}_{5} \mathrm{~W}(1168.69)\end{array}$ & Green & 203 & $\begin{array}{c}59.57 \\
(59.61)\end{array}$ & $\begin{array}{c}5.31 \\
(5.34)\end{array}$ & $\begin{array}{l}7.12 \\
(7.18)\end{array}$ & $\begin{array}{l}\cdots . . \\
\cdots . .\end{array}$ & $\begin{array}{l}15.70 \\
(15.74)\end{array}$ & 82.8 \\
\hline 3. & $\begin{array}{l}\left(\mathrm{Ph}_{3} \mathrm{P}\right)_{2} \mathrm{NH}_{2}\left[\mathrm{WO}(\mathrm{CN})_{3} \mathrm{PBU}\right] \cdot 3 \mathrm{H}_{2} \mathrm{O} \\
\mathrm{C}_{52} \mathrm{H}_{59} \mathrm{P}_{2} \mathrm{~N}_{7} \mathrm{O}_{5} \mathrm{~W}(1108.09)\end{array}$ & $\begin{array}{l}\text { Light } \\
\text { Green }\end{array}$ & 189 & $\begin{array}{c}56.31 \\
(56.36)\end{array}$ & $\begin{array}{c}5.30 \\
(5.36)\end{array}$ & $\begin{array}{c}8.78 \\
(8.84)\end{array}$ & $\begin{array}{l}\cdots . . \\
\cdots . .\end{array}$ & $\begin{array}{l}16.51 \\
(16.60)\end{array}$ & 79.9 \\
\hline 4. & $\begin{array}{l}\left(\mathrm{Ph}_{3} \mathrm{P}_{2} \mathrm{NH}_{2}\left[\mathrm{WO}(\mathrm{CN})_{3} \mathrm{PBTU}\right] .3 \mathrm{H}_{2} \mathrm{O}\right. \\
\mathrm{C}_{52} \mathrm{H}_{59} \mathrm{P}_{2} \mathrm{~N}_{7} \mathrm{O}_{4} \mathrm{SW} \text { (1124.09) }\end{array}$ & Green & 191 & $\begin{array}{c}55.50 \\
(55.56)\end{array}$ & $\begin{array}{c}5.21 \\
(5.29)\end{array}$ & $\begin{array}{c}8.66 \\
(8.71)\end{array}$ & $\begin{array}{l}2.78 \\
(2.84)\end{array}$ & $\begin{array}{c}15.90 \\
(16.01)\end{array}$ & 97.2 \\
\hline 5. & $\begin{array}{l}\left(\mathrm{Ph}_{3} \mathrm{P}_{2} \mathrm{NH}_{2}\left[\mathrm{WO}(\mathrm{CN})_{3} \mathrm{MBU}\right] \cdot 3 \mathrm{H}_{2} \mathrm{O}\right. \\
\mathrm{C}_{51} \mathrm{H}_{57} \mathrm{P}_{2} \mathrm{~N}_{7} \mathrm{O}_{6} \mathrm{~W}(1110.06)\end{array}$ & $\begin{array}{l}\text { Light } \\
\text { Brown }\end{array}$ & 193 & $\begin{array}{c}55.12 \\
(55.18)\end{array}$ & $\begin{array}{c}5.11 \\
(5.17)\end{array}$ & $\begin{array}{c}8.74 \\
(8.82)\end{array}$ & -.... & $\begin{array}{l}16.45 \\
(16.57)\end{array}$ & 98.0 \\
\hline & $\begin{array}{l}\left(\mathrm{Ph}_{3} \mathrm{P}_{2} \mathrm{NH}_{2}\left[\mathrm{WO}(\mathrm{CN})_{3} \mathrm{MBTU}\right] .3 \mathrm{H}_{2} \mathrm{O}\right. \\
\mathrm{C}_{51} \mathrm{H}_{57} \mathrm{P}_{2} \mathrm{~N}_{7} \mathrm{O}_{5} \mathrm{SW} \text { (1126.06) }\end{array}$ & $\begin{array}{l}\text { Light } \\
\text { Yellow }\end{array}$ & 196 & $\begin{array}{c}54.34 \\
(54.40)\end{array}$ & $\begin{array}{c}5.04 \\
(5.10)\end{array}$ & $\begin{array}{c}8.65 \\
(8.70)\end{array}$ & $\begin{array}{l}2.75 \\
(2.84)\end{array}$ & $\begin{array}{c}16.28 \\
(16.34)\end{array}$ & 81.0 \\
\hline & $\begin{array}{l}\mathrm{Cs}\left[\mathrm{WO}(\mathrm{CN})_{3} \mathrm{MBB}\right] . \mathrm{H}_{2} \mathrm{O} \\
\mathrm{CsC}_{21} \mathrm{H}_{21} \mathrm{~N}_{5} \mathrm{O}_{4} \mathrm{~W} \quad(723.25)\end{array}$ & $\begin{array}{l}\text { Light } \\
\text { Green }\end{array}$ & 222 & $\begin{array}{c}34.81 \\
(34.87)\end{array}$ & $\begin{array}{c}2.04 \\
(2.11)\end{array}$ & $\begin{array}{c}9.59 \\
(9.67)\end{array}$ & $\begin{array}{l}\cdots . . \\
\cdots \cdots\end{array}$ & $\begin{array}{c}25.36 \\
(25.44)\end{array}$ & 85.0 \\
\hline 8. & $\begin{array}{l}\mathrm{Cs}\left[\mathrm{WO}(\mathrm{CN})_{3} \mathrm{PBB}\right] \cdot \mathrm{H}_{2} \mathrm{O} \\
\mathrm{Cs}_{22} \mathrm{H}_{24} \mathrm{~N}_{6} \mathrm{O}_{3} \mathrm{~W} \quad(736.26)\end{array}$ & $\begin{array}{l}\text { Greenish } \\
\text { yellow }\end{array}$ & 224 & $\begin{array}{c}35.81 \\
(35.89)\end{array}$ & $\begin{array}{c}3.22 \\
(3.28)\end{array}$ & $\begin{array}{c}11.33 \\
(11.40)\end{array}$ & $\begin{array}{l}\cdots . . \\
\cdots \cdots\end{array}$ & $\begin{array}{c}24.86 \\
(24.99)\end{array}$ & 79.0 \\
\hline 9. & $\begin{array}{l}\mathrm{Cs}\left[\mathrm{WO}(\mathrm{CN})_{3} \mathrm{PBU}\right] . \mathrm{H}_{2} \mathrm{O} \\
\mathrm{Cs}_{16} \mathrm{H}_{21} \mathrm{~N}_{6} \mathrm{O}_{3} \mathrm{~W} \quad(661.19)\end{array}$ & Green & 212 & $\begin{array}{c}28.95 \\
(29.06)\end{array}$ & $\begin{array}{c}3.12 \\
(3.20)\end{array}$ & $\begin{array}{c}12.61 \\
(12.70)\end{array}$ & $\begin{array}{l}\cdots . . \\
\cdots \cdots\end{array}$ & $\begin{array}{l}27.65 \\
(27.82)\end{array}$ & 93.5 \\
\hline 10 & $\begin{array}{l}\mathrm{Cs}\left[\mathrm{WO}(\mathrm{CN})_{3} \mathrm{PBTU}\right] . \mathrm{H}_{2} \mathrm{O} \\
\mathrm{CsC}_{16} \mathrm{H}_{21} \mathrm{~N}_{6} \mathrm{O}_{2} \mathrm{SW} \\
\text { (677.19) }\end{array}$ & $\begin{array}{l}\text { Greenish } \\
\text { yellow }\end{array}$ & 230 & $\begin{array}{c}28.30 \\
(28.38)\end{array}$ & $\begin{array}{c}3.05 \\
(3.12)\end{array}$ & $\begin{array}{c}12.32 \\
(12.40)\end{array}$ & $\begin{array}{c}4.64 \\
(4.72)\end{array}$ & $\begin{array}{c}27.00 \\
(27.17)\end{array}$ & 96.0 \\
\hline 11 & $\begin{array}{l}\mathrm{Cs}\left[\mathrm{WO}(\mathrm{CN})_{3} \mathrm{MBU}\right] . \mathrm{H}_{2} \mathrm{O} \\
\mathrm{CsC}_{15} \mathrm{H}_{19} \mathrm{~N}_{6} \mathrm{O}_{4} \mathrm{~W}\end{array}$ & Green & 228 & $\begin{array}{c}27.07 \\
(27.16)\end{array}$ & $\begin{array}{c}2.80 \\
(2.88)\end{array}$ & $\begin{array}{c}12.57 \\
(12.66)\end{array}$ & $\ldots$. & $\begin{array}{c}27.60 \\
(27.74)\end{array}$ & 87.2 \\
\hline 12 & $\begin{array}{l}\mathrm{Cs}\left[\mathrm{WO}(\mathrm{CN})_{3} \mathrm{MBTU}\right] . \mathrm{H}_{2} \mathrm{O} \\
\mathrm{CsC}_{15} \mathrm{H}_{19} \mathrm{~N}_{6} \mathrm{O}_{3} \mathrm{SW}(679.18)\end{array}$ & $\begin{array}{l}\text { Light } \\
\text { Brown }\end{array}$ & 220 & $\begin{array}{r}26.45 \\
(26.52) \\
\end{array}$ & $\begin{array}{c}2.73 \\
(2.81)\end{array}$ & $\begin{array}{c}12.28 \\
(12.36) \\
\end{array}$ & $\begin{array}{c}4.62 \\
(4.71) \\
\end{array}$ & $\begin{array}{c}26.88 \\
(27.09) \\
\end{array}$ & 88.9 \\
\hline
\end{tabular}

Infrared spectra

In order to determine the mode of bonding of Mannich base ligands with tungsten, the IR spectra of ligands were compared with those of corresponding complexes. The IR spectra (Table 2) of all the complexes exhibit bands in the region $940-970 \mathrm{~cm}^{-1}$ which can be assigned to the stretching vibrations of the $\mathrm{W}=\mathrm{O}$ group ${ }^{20}$. In the $\mathrm{CN}$ stretching region the IR spectra show two bands in the region of 2066 to $2135 \mathrm{~cm}^{-1}$.

Table 2. Important IR bands $\left(\mathrm{cm}^{-1}\right)$ of the oxotungsten(IV) complexes

\begin{tabular}{|c|c|c|c|c|c|}
\hline S.No. & Complex & $v(\mathrm{~W}=\mathrm{O})$ & $v(\mathrm{CN})$ & $\begin{array}{c}v(\mathrm{C}=\mathrm{Z}) \\
\mathrm{Z}=\mathrm{O} \text { or } \mathrm{S}\end{array}$ & $v(\mathrm{C}-\mathrm{N}-\mathrm{C})$ \\
\hline 1. & $\left(\mathrm{Ph}_{3} \mathrm{P}\right)_{2} \mathrm{NH}_{2}\left[\mathrm{WO}(\mathrm{CN})_{3} \mathrm{MBB}\right] .3 \mathrm{H}_{2} \mathrm{O}$ & 956 & 2074,2121 & 1587 & 1112,1101 \\
\hline 2. & $\left(\mathrm{Ph}_{3} \mathrm{P}\right)_{2} \mathrm{NH}_{2}\left[\mathrm{WO}(\mathrm{CN})_{3} \mathrm{PBB}\right] .3 \mathrm{H}_{2} \mathrm{O}$ & 948 & 2088, 2101 & 1598 & 1111,1103 \\
\hline 3. & $\left(\mathrm{Ph}_{3} \mathrm{P}\right)_{2} \mathrm{NH}_{2}\left[\mathrm{WO}(\mathrm{CN})_{3} \mathrm{PBU}\right] .3 \mathrm{H}_{2} \mathrm{O}$ & 940 & 2066,2115 & 1590 & 1118,1101 \\
\hline 4. & $\left(\mathrm{Ph}_{3} \mathrm{P}\right)_{2} \mathrm{NH}_{2}\left[\mathrm{WO}(\mathrm{CN})_{3} \mathrm{PBTU}\right] .3 \mathrm{H}_{2} \mathrm{O}$ & 951 & 2077,2108 & 1276 & 1120,1100 \\
\hline 5. & $\left(\mathrm{Ph}_{3} \mathrm{P}\right)_{2} \mathrm{NH}_{2}\left[\mathrm{WO}(\mathrm{CN})_{3} \mathrm{MBU}\right] .3 \mathrm{H}_{2} \mathrm{O}$ & 953 & 2069,2118 & 1595 & 1115,1101 \\
\hline 6. & $\left(\mathrm{Ph}_{3} \mathrm{P}\right)_{2} \mathrm{NH}_{2}\left[\mathrm{WO}(\mathrm{CN})_{3} \mathrm{MBTU}\right] \cdot 3 \mathrm{H}_{2} \mathrm{O}$ & 956 & 2093,2116 & 1272 & 1114,1100 \\
\hline 7. & $\mathrm{Cs}\left[\mathrm{WO}(\mathrm{CN})_{3} \mathrm{MBB}\right] \cdot \mathrm{H}_{2} \mathrm{O}$ & 947 & 2084,2119 & 1589 & 1112,1102 \\
\hline 8. & $\mathrm{Cs}\left[\mathrm{WO}(\mathrm{CN})_{3} \mathrm{PBB}\right] \cdot \mathrm{H}_{2} \mathrm{O}$ & 970 & 2079,2125 & 1599 & 1113,1101 \\
\hline 9. & $\mathrm{Cs}\left[\mathrm{WO}(\mathrm{CN})_{3} \mathrm{PBU}\right] \cdot \mathrm{H}_{2} \mathrm{O}$ & 958 & 2085,2135 & 1604 & 1121,1103 \\
\hline 10. & $\mathrm{Cs}\left[\mathrm{WO}(\mathrm{CN})_{3} \mathrm{PBTU}\right] \cdot \mathrm{H}_{2} \mathrm{O}$ & 965 & 2083,2132 & 1280 & 1114,1100 \\
\hline 11. & $\mathrm{Cs}\left[\mathrm{WO}(\mathrm{CN})_{3} \mathrm{MBU}\right] \cdot \mathrm{H}_{2} \mathrm{O}$ & 966 & 2080,2129 & 1602 & 1116,1101 \\
\hline 12. & $\mathrm{Cs}\left[\mathrm{WO}(\mathrm{CN})_{3} \mathrm{MBTU}\right] \cdot \mathrm{H}_{2} \mathrm{O}$ & 962 & 2099,2132 & 1271 & 1113,1102 \\
\hline
\end{tabular}


The $v(\mathrm{C}=\mathrm{O})$ absorption band at $1610-1650 \mathrm{~cm}^{-1}$ in the free MBB, PBB, PBU and MBU and $v(\mathrm{C}=\mathrm{S})$ modes of PBTU and MBTU at $1290-1295 \mathrm{~cm}^{-1}$ are lowered by 20 to $25 \mathrm{~cm}^{-1}$ in the complexes indicating the involvement of carbonyl oxygen $(\mathrm{O})$ or thiocarbonyl sulphur (S) in bonding with the tungsten. The $v(\mathrm{C}-\mathrm{N}-\mathrm{C})$ mode of morpholine and piperidine ring around 1104-1130 $\mathrm{cm}^{-1}$ also show a negative shift in the complexes indicating the involvement of ring nitrogen in bonding with tungsten.

There is also negative shift in stretching and bending modes of $\mathrm{N}-\mathrm{H}$ bands of morpholine and piperidine ring in complexes which indicate involvement of ring nitrogen in $\mathrm{W}-\mathrm{N}$ bond formation. $\mathrm{A}$ slight positive shift in $\mathrm{C}-\mathrm{O}-\mathrm{C}$ stretching mode of morpholine ring shows that morpholine ring does not involve its oxygen atom in bond formation with tungsten. These IR bands suggest that in all the complexes the ligands MBB, PBB, PBU, PBTU, MBU and MBTU behave in bidentate chelating mode coordinating the metal through carbonyl $(\mathrm{O})$ or thiocarbonyl(S) and the ring nitrogen.

\section{Electronic spectra}

The electronic spectra (Table 3) of the complexes exhibit intense spectral peaks in the region $360-415 \mathrm{~nm}$. A peak of low intensity is also observed in the region 560-620 nm. The bands observed in the region $360-415 \mathrm{~nm}$ can be assigned to charge-transfer to metal (LMCT) transitions. The weak bands observed in the region 560-620 $\mathrm{nm}$ can be attributed to $d-d$ transitions.

Table 3. Electronic spectra of the oxotungsten(IV) complexes

\begin{tabular}{clcc}
\hline S. No. & \multicolumn{1}{c}{ Complex } & $\begin{array}{c}\text { CTLM } \\
\text { transitions, nm }\end{array}$ & $\begin{array}{c}d \text { - } d \text { transitions, } \\
\text { nm }\end{array}$ \\
\hline 1. & $\left(\mathrm{Ph}_{3} \mathrm{P}\right)_{2} \mathrm{NH}_{2}\left[\mathrm{WO}(\mathrm{CN})_{3} \mathrm{MBB}\right] .3 \mathrm{H}_{2} \mathrm{O}$ & 367,399 & 566 \\
2. & $\left(\mathrm{Ph}_{3} \mathrm{P}\right)_{2} \mathrm{NH}_{2}\left[\mathrm{WO}(\mathrm{CN})_{3} \mathrm{PBB}\right] .3 \mathrm{H}_{2} \mathrm{O}$ & 360,402 & 617 \\
3. & $\left(\mathrm{Ph}_{3} \mathrm{P}\right)_{2} \mathrm{NH}_{2}\left[\mathrm{WO}(\mathrm{CN})_{3} \mathrm{PBU}\right] .3 \mathrm{H}_{2} \mathrm{O}$ & 362,412 & 609 \\
4. & $\left(\mathrm{Ph}_{3} \mathrm{P}\right)_{2} \mathrm{NH}_{2}\left[\mathrm{WO}(\mathrm{CN})_{3} \mathrm{PBTU}\right] .3 \mathrm{H}_{2} \mathrm{O}$ & 375,402 & 601 \\
5. & $\left(\mathrm{Ph}_{3} \mathrm{P}\right)_{2} \mathrm{NH}_{2}\left[\mathrm{WO}(\mathrm{CN})_{3} \mathrm{MBU}\right] .3 \mathrm{H}_{2} \mathrm{O}$ & 364,415 & 609 \\
6. & $\left(\mathrm{Ph}{ }_{3} \mathrm{P}\right)_{2} \mathrm{NH}_{2}\left[\mathrm{WO}(\mathrm{CN})_{3} \mathrm{MBTU}\right] .3 \mathrm{H}_{2} \mathrm{O}$ & 375,401 & 607 \\
7. & $\mathrm{Cs}\left[\mathrm{WO}(\mathrm{CN})_{3} \mathrm{MBB}\right] . \mathrm{H}_{2} \mathrm{O}$ & 366,413 & 569 \\
8. & $\mathrm{Cs}\left[\mathrm{WO}(\mathrm{CN})_{3} \mathrm{PBB}\right] . \mathrm{H}_{2} \mathrm{O}$ & 383,404 & 564 \\
9. & $\mathrm{Cs}\left[\mathrm{WO}(\mathrm{CN})_{3} \mathrm{PBU}\right] . \mathrm{H}_{2} \mathrm{O}$ & 381,403 & 620 \\
10. & $\mathrm{Cs}\left[\mathrm{WO}(\mathrm{CN})_{3} \mathrm{PBTU}\right] . \mathrm{H}_{2} \mathrm{O}$ & 388,401 & 614 \\
11. & $\mathrm{Cs}\left[\mathrm{WO}(\mathrm{CN})_{3} \mathrm{MBU}\right] . \mathrm{H}_{2} \mathrm{O}$ & 385,408 & 560 \\
12. & $\mathrm{Cs}\left[\mathrm{WO}(\mathrm{CN})_{3} \mathrm{MBTU}\right] . \mathrm{H}_{2} \mathrm{O}$ & 363,411 & 566 \\
\hline
\end{tabular}

\section{TGA/DTA studies}

The thermogravimetric and differential thermal analysis studies have been made over a temperature range of $25-800{ }^{\circ} \mathrm{C}$. The TGA curves for the complexes 1-12 indicate (Figure 1) that water molecules are weakly bonded. In case of complexes 1-6, three water molecules are released around a temperature of $80-100{ }^{\circ} \mathrm{C}$ and thereafter the complexes are stable up to $800{ }^{\circ} \mathrm{C}$. Weight loss (found/calcd.) in \% for complexes 1-6 are: 4.59/4.61, 4.59/4.62, 4.85/4.87, 4.77/4.80, 4.78/4.86 and 4.71/4.79 respectively. The TGA curves (Figure 2) for the complexes 7-12 indicate release of one water molecule around a temperature of $95-110{ }^{\circ} \mathrm{C}$. After dehydration, these complexes are stable up to $800{ }^{\circ} \mathrm{C}$. Weight loss (found/calcd.) in \% for complexes 7-12 are: $2.40 / 2.48,2.37 / 2.44,2.64 / 2.72,2.54 / 2.65,2.60 / 2.71$ and 2.53/2.65 respectively. The loss of water molecules was also indicated by a sharp endothermic DTA peak in the complexes.

\section{${ }^{1}$ H NMR Spectra}

The ${ }^{1} \mathrm{H}$ NMR spectrum of the representative ligands, morpholinobenzyl urea (MBU) was recorded in deutrated methanol. The spectrum shows a triplet at $\delta 3.34$ for $\mathrm{N}_{-} \mathrm{CH}_{2}$ of morpholine ring for MBU. The methylidyne proton of Ph-CH-NH appears as a septet at $\delta 7.54$. 
In the complex $\mathrm{Cs}\left[\mathrm{WO}(\mathrm{CN})_{3} \mathrm{MBU}\right] \cdot \mathrm{H}_{2} \mathrm{O}$, the peaks corresponding to four protons of $-\mathrm{CH}_{2}$ groups of $\mathrm{N}_{-} \mathrm{CH}_{2}$ in morpholine ring undergo downfield shift with $\delta 3.52$. This is due to coordination of ring nitrogen of piperidine with tungsten.

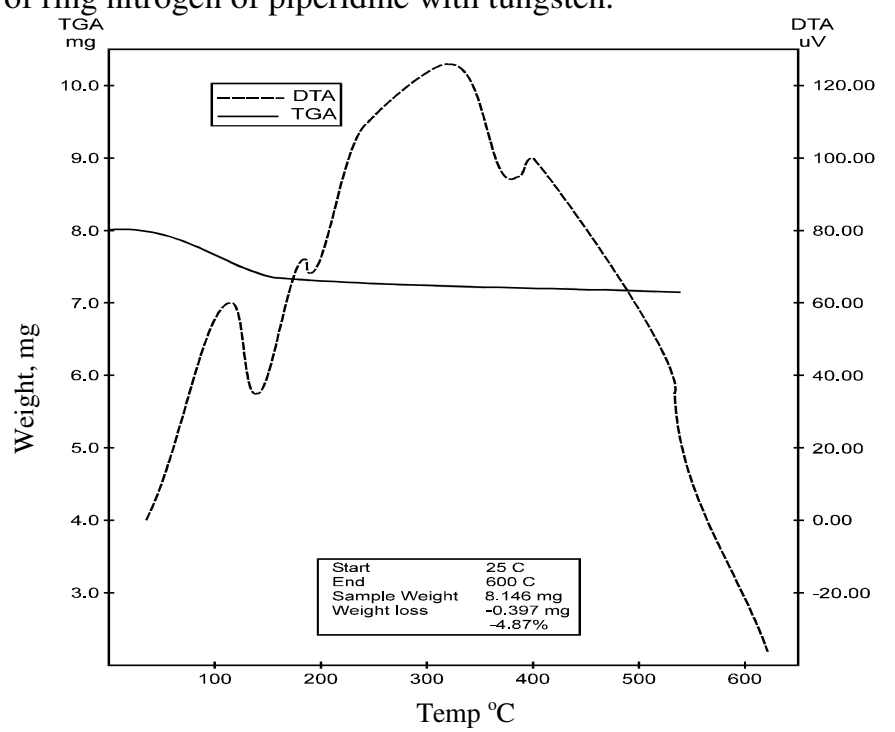

Figure 1. TGA/DTA curve of $\left(\mathrm{Ph}_{3} \mathrm{P}\right)_{2} \mathrm{NH}_{2}\left[\mathrm{WO}(\mathrm{CN})_{3} \mathrm{PBU}\right] .3 \mathrm{H}_{2} \mathrm{O}$

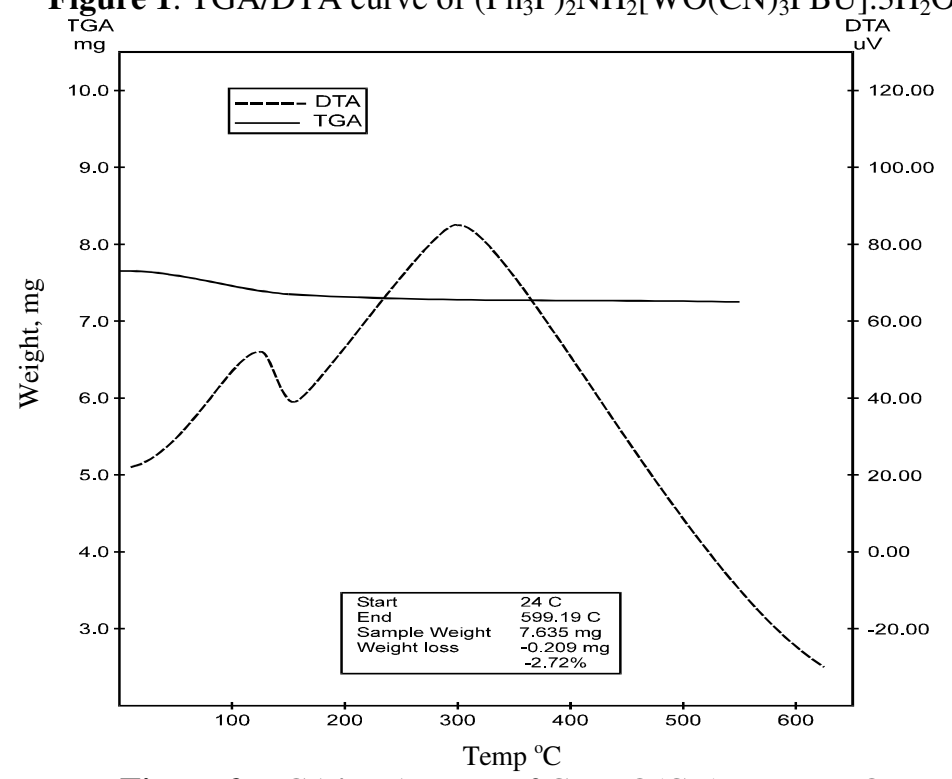

Figure 2. TGA/DTA curve of $\mathrm{Cs}\left[\mathrm{WO}(\mathrm{CN})_{3} \mathrm{PBU}\right] \cdot \mathrm{H}_{2} \mathrm{O}$

\section{Conclusion}

From the physicochemical and spectral studies, we proposed that these complexes are of general composition, $\left[\mathrm{WO}(\mathrm{CN})_{3} \mathrm{~L}-\mathrm{L}\right]^{-}$(where $\mathrm{L}-\mathrm{L}=$ morpholinobenzyl benzamide $(\mathrm{MBB})$, piperidinobenzyl benzamide (PBB), piperidinobenzyl urea (PBU), piperidinobenzyl thiourea (PBTU), morpholinobenzyl urea (MBU) and morpholinobenzyl thiourea (MBTU)). 
The representative structure proposed for the complexes is

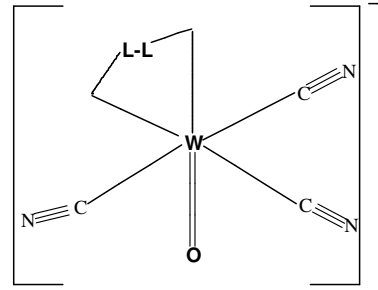

\section{References}

Where L-L $=$ MBB, PBB, PBU, PBTU, MBU and MBTU.

1. Dudek M and Samotus A, Transition Met Chem., 1985, 10, 271.

2. Basson S S, Leipoldt J G, Potgieter I M and Roodt A, Inorg Chim Acta., 1985, 103,121.

3. Leipoldt J G, Basson S S, Roodt A and Potgieter I M, S Afr J Chem., 1986, 39, 179.

4. Szklarzewicz J, Matoga D, Samotus A, Burgess J, Fawcett J and Russell D R, Croatica Chim Acta, 2001,74, 529.

5. Leipoldt J G, Basson S S, Roodt A and Purcell W, Polyhedron, 1992, 11, 2277.

6. Roodt A, Leipoldt J G, Basson S S and Potgieter I M, Transition Met Chem., 1990, 15, 439.

7. Robinson P R, Schlemper E O and Murmann R K, Inorg Chem., 1975, 14, 2035.

8. Wieghardt K, Dahmann G B, Hzizback W, Swiridorff W S and Weiss J, Z Anorg Allg Chem., 1983, 44, 499.

9. Potgieter I M, Basson S S, Roodt A and Leipoldt J G, Transition Met Chem., 1988, 13, 209.

10. Smit J P, Purcell W, Roodt A and Leipoldt J G, Polyhedron, 1993, 12, 2271.

11. Leipoldt J G, Van Eldik R, Basson S S and Roodt A, Inorg Chem., 1986, 25, 4639.

12. Roodt A, Leipoldt J G, Basson S S and Potgieter I M, Transition Met Chem., 1988, 13, 336.

13. Purcell W, Roodt A, Basson S S and Leipoldt J G, Transition Met Chem., 1989, 14, 224-226.

14. Purcell W, Roodt A and Leipoldt J G, Transition Met Chem., 1991, 16, 339.

15. Leipoldt J G, Basson S S, Potgieter I M and Roodt A, Inorg Chem., 1987, 26, 57.

16. Samotus A, Kanas A, Glug W and Szklarzewicz J, Transition Met Chem., 1991, 16, 614.

17. Basson S S, Leipoldt J G and Potgieter I M, Inorg Chim Acta, 1984, 87, 71.

18. Szklarzewicz J, Samotus A, Alcock N W and Moll M, J Chem Soc, Dalton Trans., 1990, 10, 2959.

19. Leipoldt J G, Basson S S, Roodt A and Potgieter I M, Transition Met Chem., 1986, 11, 323.

20. Roodt A, Basson S S and Leipoldt J G, Polyhedron, 1994, 13, 599.

21. Venkatesa Prabhu G and Venkappayya D, J Indian Chem Soc., 1995, 72, 511.

22. Raman N, Vimalaramani R and Thangaraja C, Indian J Chem., 2004, 43A, 2357.

23. Vogel A I, Quantitative Inorg. Analysis, Longman Group Limited, 1968

24. Nowicka B, Samotus A, Szklarzewicz J, Heinemann F and Kisch H, J Chem Soc, Dalton Trans., 1998, 23, 4009. 


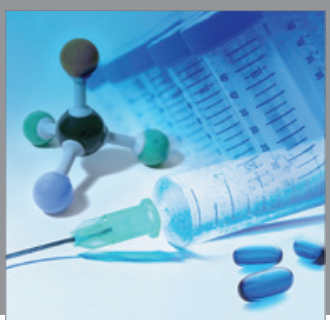

International Journal of

Medicinal Chemistry

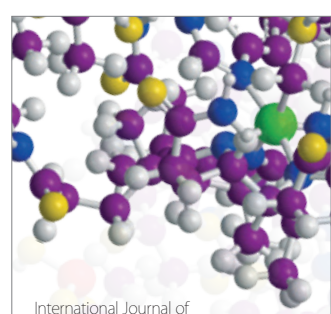

Carbohydrate Chemistry

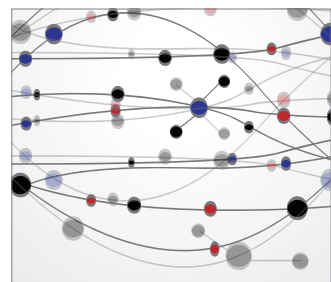

The Scientific World Journal
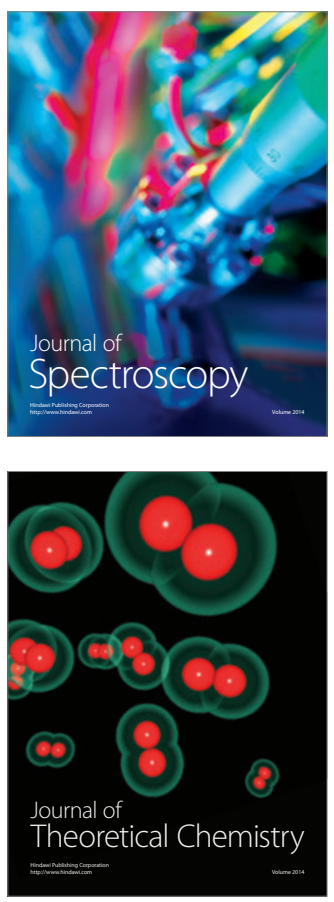
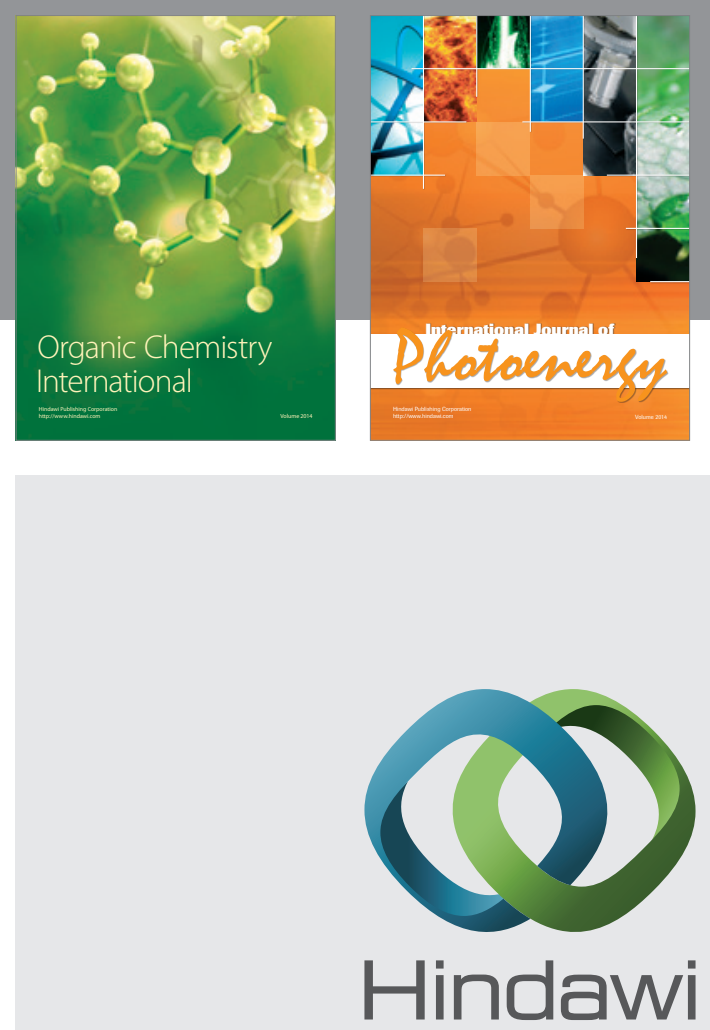

Submit your manuscripts at

http://www.hindawi.com
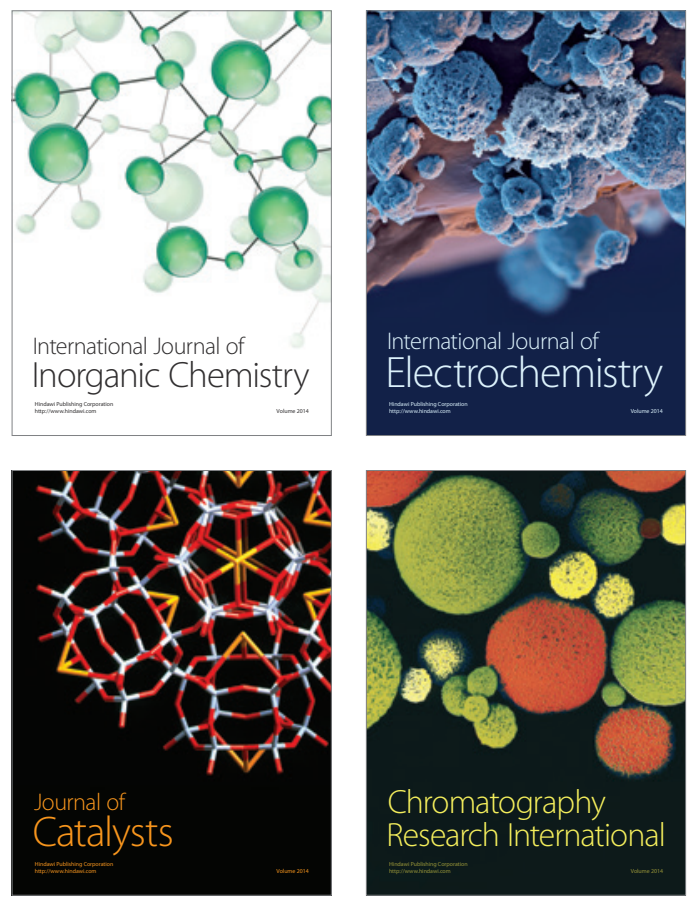
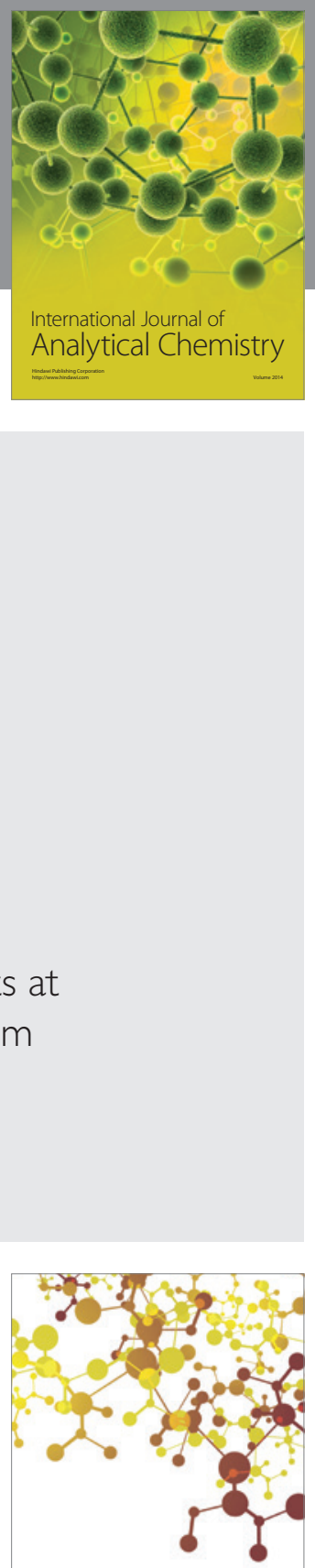

Journal of

Applied Chemistry
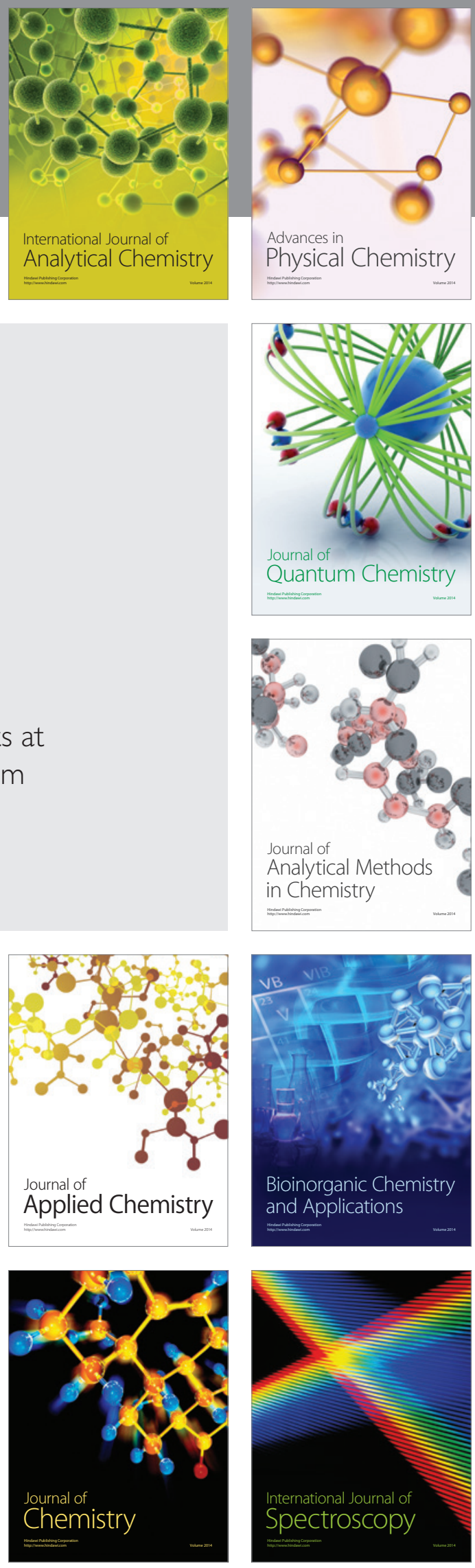